\begin{tabular}{l|l} 
Proceedings of the & $\begin{array}{l}\text { An Official Publication } \\
\text { of the Informing Science Institute } \\
\text { InformingScience.org }\end{array}$ \\
$\begin{array}{l}\text { Informing Science }+ \\
\text { Education Conference }\end{array}$ & $\begin{array}{l}\text { InformingScience.org/Publications } \\
\text { In Technology }\end{array}$
\end{tabular}

July 31 - August 5 2017, Ho Chi Minh City (Saigon), Vietnam

\title{
COMPARISON OF APPLICANT'S RESULTS FOR STUDIES FROM RUSSIA AND VIETNAM AT THE UNIVERSITY OF ECONOMICS, PRAgue
}

$\begin{array}{lll}\text { Milos Maryska* } & \begin{array}{l}\text { University of Economics, Prague, } \\ \text { Prague Czech Republic }\end{array} & \text { maryskam@,vse.cz } \\ \text { Petr Doucek* } & \begin{array}{l}\text { University of Economics, Prague, } \\ \text { Prague Czech Republic }\end{array} & \text { doucek@,vse.cz } \\ \text { Lea Nedomova } & \begin{array}{l}\text { University of Economics, Prague, } \\ \text { Prague Czech Republic }\end{array} & \\ \text { * Corresponding author } & \end{array}$

\begin{abstract}
Aim/Purpose The aim of this paper is analysis of applicants for study at the University of Economics, Prague (UEP) that are coming from foreign countries. The second aim is to learn the graduation rate of foreign students.

Background

Knowledge about applicants results are important for changing entrance exams according to the changing situation in high school education systems and according to the changing requirements coming from teachers at UEP. The background question is, if the both components of entrance exams should have the same significance.
\end{abstract}

Methodology Entrance exams results were analysed for 2009-2016 period. We used standard statistics methods supported by the IBM SPSS tool and Microsoft Excel. All data were processed by way of Microsoft SQL Server. We analyzed the faculties that require Mathematics and English entrance exams. We are comparing mainly results of applicants from Russia and Vietnam. For graduation rate estimations the logit model approach has been applied. The data for our analysis came from UEP information systems and hard-copy applications and were then set anonymous.

Contribution Detailed analysis of situation at the UEP and guideline on how to process similar research at another universities. Paper offers comparison of Russian education system results in Mathematics and English with the education system of Vietnam. Further contribution is for Vietnamese potential applicants for study in the Czech Republic.

Accepting Editor: Eli Cohen | Received: December 5, 2016 | Revised: March 14, 2017 | Accepted: March 20, 2017.

Cite as: Maryska, M., Doucek, P., \& Nedomova, L. (2017). Comparison of applicant's results for studies from Russia and Vietnam at the University of Economics, Prague. Proceedings of the Informing Science and Information Technology Education Conference, Vietnam, pp. 23-37. Santa Rosa, CA: Informing Science Institute. Retrieved from http://www.informingscience.org/Publications/3708

(CC BY-NC 4.0) This article is licensed to you under a Creative Commons Attribution-NonCommercial 4.0 International License. When you copy and redistribute this paper in full or in part, you need to provide proper attribution to it to ensure that others can later locate this work (and to ensure that others do not accuse you of plagiarism). You may (and we encourage you to) adapt, remix, transform, and build upon the material for any non-commercial purposes. This license does not permit you to use this material for commercial purposes. 
Applicant's Results for Studies from Russia and Vietnam at the University of Economics, Prague

Findings Based on our analysis, we concluded that total number of applicants for studies was 109,996 students at the UEP during the analyzed period and applicants from Vietnam 1,686 and from Russia 7,227. For studies were accepted 717 applicants from Vietnam (42.5\%) and 1,986 applicants from Russia (27.5\%). We were also able to prove a slightly positive correlation between the number of points obtained for the English entrance exam and the mathematics entrance exam. However, this correlation goes slightly downhill over time. Further findings are from logit model of correlation between number of obtained points and successfully studies completion. The border for effective acceptance of students from this data set is approximately 170 obtained points in entrance exam.

Recommendations This analysis offers results of entrance exams on UEP from English and Mathfor Practitioners ematics. Recommendation could be held in comparison of education systems efficiency in Russia and Vietnam in these two areas with reflection requirements on students of economy at University of Economics, Prague.

Recommendation for Researchers The way of analysis, number of analyzed sample, final data and conclusions from this research. Using logit model for study success rate modeling. Offer for cooperation in analysis of entrance exams data queues.

Impact on Society Comparison of entrance exams results on University of Economics, Prague between Russian and Vietnamese applicants for study in the area of economics. Comparison of education systems effectiveness in Vietnam and in Russia in relation to economics studies in EU country.

Future Research Process this analysis in longer period and extend for another countries and nationalities. Next step planned for this is year is analysis of relation among results of Mock Entrance Exams - Entrance Exams - Study Results. This is long-term plan. In next 5 years, we should be able to answer question if there is some probability, that students failed during standard entrance exams when these students pass mock exams for example because he was in stress?

Keywords mathematics, English, economic study applicants, Vietnamese students, Russian students, entrance exams

\section{INTRODUCTION}

Integration of the Czech Republic's into European structures resulted in joining the Bologna Declaration (Stastna \& Walterova, 2014). The integration of the Bologna Declaration into Czech education system results in changing the university education system (Flegl \& Vltavska, 2013; Musil \&Fischer, 2015; Nedomova, Doucek, \& Maryška, 2015; Sigmund, 2015; Sperkova \& Nedomova, 2015) and opening and making available the study programs of Czech universities to foreign students (Kohanova, 2012; Kuncova \& Mulac, 2015; OECD, 2009). Foreign students can apply for study program in Czech or for foreign-language study programs that are usually in English, German, or Russian. Study programs in foreign-language are paid. For this reason this paper is about applicants which are applying for study programs in Czech. If foreign students apply for Czech study programs, they must pass exam from Czech language to prove that they are fluent in the Czech language (Vysokeskoly, 2010). These are foreign students who either have some kind of relationship to the Czech Republic (e.g., one of their parents is Czech) or come from Slavic countries where the language is so similar that they can become fluent in Czech in one year - these are usually students from Ukraine, Russia, Belorussia, etc. or from Russian-speaking enclaves in the Central Asian republics of the former Soviet Union). The university education systems of the Czech Republic in the context of ICT education and its results are described, for example, in these studies: Hanclova, 2015; Hanclova, Rozehnal, Ministr, \& Tvrdikova, 2015; Nedomova, Maryska, \& Doucek, 2014; Pavlicek, 2013; Reznicek, Smutny, 
Kalina, \& Galba, 2013. This article shows the knowledge of students from Vietnam and Russia upon their admission to the UEP during 2009 - 2016 and provides information about correlation between points gained during entrance exams and probability of finishing their studies at UEP.

Sources for this research were split on three levels. Nedomova et al. (2014) presented mainly Czech sources, which cover all national and university specifics. Hanclova et al. (2015) are sources from Slovak Republic, where entrance exams are rather like ours. The main source deals with entrance exams from mathematics (Kohanova, 2012), but this source did not analyse obtained points, but the structure of tests for entrance exams. Further sources from the world are involved in English exams results analysis. Analysis of knowledge of English of applicants for studies in the Japan is analyses in Kitao and Kitao (2009) and similar study in Iran is analyzed in Razmjoo and Tabrizi 2010). From financial point of view is analysis of entrance exams made in USA in a paper by Klasik (2012). Analysis of knowledge from Physics was realized in Turkey in year 2000-2003 (Azar, 2005). Some relations to our research could be visible in analysis of Kitao and Kitao (2009). The problem is that they have a data set with only 31 respondents from 4 universities in Japan and the topic of this research was focused on vocabulary frequency not on final exams results.

\section{Problem Formulation and Research Questions}

The presented analysis is based on scientific research as well as on the analysis of data about applicants that the UEP has been collecting for a long time. The target group of this analysis are foreign students from Russia and Vietnam who applied for study programs taught in the Czech language. This analysis also focuses on undergraduate study applications only. We are analyzing dependency between amount of points from entrance exams and probability of finishing their bachelor studies.

We also analyzed the trend in the number of foreign students from Russia and Vietnam at the UEP during the analyzed time period.

We consider citizenship only and we are not concerned about nationality. Citizenship is specified in application for study.

For the purposes of presentation in this article, we formulated the following research questions.

- RQ 1: Russian applicants have higher score in Mathematics than Vietnamese ones.

- RQ 2: Russian applicants have higher score in English than Vietnamese ones.

- RQ 3: Average score from English is increasing on undergraduate level by both nationalities.

- RQ 4: Average score from Mathematics is increasing on undergraduate level by both nationalities.

The formulation of research questions is based on the presumption that the Russian education system is more like the European and the Czech one as well. This presumption also implies that taught subjects prepare applicants better for study on European HEIs (Higher Education Institutions) or universities than Vietnamese education system.

For specification of the evaluation of results we state, for the sake of completeness, that there are six faculties at the University of Economics, Prague at this time - Faculty of Finance and Accounting (FFA), Faculty of International Relations (FIR), Faculty of Business Administration (FBA), Faculty of Informatics and Statistics (FIS), Faculty of Economics (FE), Faculty of Management (FMJH). The last two faculties are not included into research data sample.

\section{Material AND MEthods (DATa COLlECtion)}

The UEP information system, which includes the complete data of applicants for all academic disciplines of all levels, was our basic source of data. This system includes both the basic identification data and the entrance exam results of the applicants. Our analysis focused only on foreign students applying for undergraduate study programs at the UEP during the analyzed time period. Foreign 
students are considered to be those who checked a citizenship other than the Czech citizenship in their applications. In view of the nature of the data collected about the applicants, we have no information about where they actually live.

We analyzed the data in compliance with Act No. 101/2000 of Coll., on the protection of personal data. Based on its provisions, we are obliged to set anonymous the analyzed data and to process them in a way that makes it impossible to track down specific applicants or to obtain their personal data (date of birth, first name, last name, etc.). We analyzed individual years as well as the group of data as a whole.

In the case of logit function we are analyzing the correlation between an entrance exam result and a successful or failed completion of studies; we transformed the completion of studies into the binary values of 0 and 1 , where 0 - a student failed his studies and 1 - a student successfully completed his studies. To calculate the correlation values, we used the logistic regression, where the binary variable of studies completion was the dependent variable and the number of points obtained in an entrance exam was only one independent quantitative continuous variable (Kuncova \& Wasserbauer, 2007; Rezankova, 2010). The probability of studies completion is marked as p. Then:

$$
\ln (p / 1-p)=\beta_{0}+\beta_{1} \text { NPEE }
$$

where

NPEE is number of points from entrance exams,

$\beta_{\circ}$ constant,

$\beta_{1}$ increment - points from entrance exam,

p - probability of successful studies completion.

To calculate the actual correlation, we used the SPSS application, and to accept or reject the null hypothesis of regression parameters being zero we used the Wald test (Rezankova, 2010) where we rejected this hypothesis if the Wald test was higher than zero.

The correlation (1) shows that

$$
\mathrm{p}=\mathrm{e}^{(\beta \mathrm{O}+\beta 1 * \mathrm{NPEE})} / 1+\mathrm{e}^{(\beta \mathrm{O}+\beta 1 * \mathrm{NPEE})}
$$

where

ßo - constant,

$\beta 1$ - increment - points from entrance exam,

NPEE - is number of points obtained in an entrance exam,

$\mathrm{p}$ - the estimated probability of successful studies completion if a certain number of points is obtained in an entrance exam.

\section{General Data Characteristics}

The UEP received 109,996 application forms for bachelor studies since year 2009.

We obtained a total of 109,996 records of applications for the analyzed time period. Each record includes information about an application of one applicant. If an applicant applied for several study programs, he/she has several records. An applicant's basic attributes, which are anonymously analyzed, are as follows: gender, study program, academic discipline, faculty, type of study, entrance exam results, and admission or non-admission. If the student is accepted for studies, then those records provides information about their studies also. We have information about all marks received during their studies and information if the students finished his studies and when (year, which semester etc.) 
The actual data analysis was performed in MS Excel and the model was formulated in the SPSS computer application. A total of 8,913 records of foreign students from Vietnam and Russia from all faculties and for the entire analyzed time period were analyzed.

\section{RESULTS AND DISCUSSION}

\section{GENERAL OVERVIEW}

The UEP received 109,996 application forms since year 2009 and 8,913 are from foreign student from Russia and Vietnam which are main objectives of this paper. From those 8,913 we have 4,152 records $(46.6 \%)$ with results from Mathematics and English. The difference between those numbers is caused by the fact that some of applicants are not arriving to entrance exams which are written and have to be taken at the UEP. For this reason there is a difference between the number of applicants and the number of records from entrance exam.

The Table 1 provides information about structure of the whole sample of applicants which are applying for studies at UEP. You can see that the highest number of applicants is for studies at FBA and FE. But we see that number of applications is decreasing in time which is caused by demographic characteristic of the Czech society.

Table 1. Amount of All Applicants per Year and Faculty

\begin{tabular}{|c|c|c|c|c|c|c|c|}
\hline Year & FFA & FIS & FMJH & FIR & FBA & FE & Total \\
\hline 2009 & 2,747 & 2,306 & 999 & 2,982 & 4,267 & 3,215 & 16,984 \\
\hline 2010 & 2,690 & 2,333 & 1,169 & 2,858 & 4,158 & 3,322 & 17,162 \\
\hline 2011 & 2,765 & 2,516 & 1,118 & 3,030 & 4,290 & 2,715 & 16,384 \\
\hline 2012 & 2,672 & 2,470 & 954 & 2,855 & 4,047 & 2,242 & 14,810 \\
\hline 2013 & 2,478 & 2,405 & 856 & 2,720 & 3,390 & 1,820 & 13,011 \\
\hline 2014 & 2,105 & 1,969 & 775 & 2,521 & 2,678 & 1,568 & 11,079 \\
\hline 2015 & 1,765 & 1,799 & 641 & 2,157 & 2,702 & 1,588 & 10,475 \\
\hline 2016 & 1,544 & 1,623 & 464 & 1,877 & 2,515 & 1,316 & 91,11 \\
\hline Total & 18,766 & 17,421 & 6,976 & 21,000 & 28,047 & 17,786 & 109,016 \\
\hline
\end{tabular}

The structure of the sample from the gender point of view shows that $54 \%$ of applicants are female.

Table 2. Amount of all applicants according to the gender

\begin{tabular}{|l|c|c|}
\hline Gender & $\mathbf{N}$ & $\mathbf{\%}$ \\
\hline Male & 50,512 & $45.9 \%$ \\
\hline Female & 59,484 & $54.1 \%$ \\
\hline
\end{tabular}

Table 3 and Table 4 provide basic statistical characteristics about the whole sample of applicants for studies. Based on number of records from entrance exams (54,228 - see Table 3) and total number of applications $(109,996)$ we calculated, that only $49.3 \%$ of applicants arrived to their entrance exam. Mean value of the points from English is 68.710 and from Mathematics 60.52 for the whole sample with standard deviation $17.227 / 24.771$. When we compare those numbers with number in Table 4 where are results of all applicants accepted for studies, we see that these results are much better. 
Applicant's Results for Studies from Russia and Vietnam at the University of Economics, Prague

Table 3. Descriptive Statistics for the Whole Sample of Applicants

\begin{tabular}{|l|l|l|l|l|l|l|}
\hline & N & Mean & Std. Deviation & Variance & Kurtosis & Skewness \\
\hline English & 54,228 & 68.710 & 17.227 & 296.768 & 0.545 & -0.634 \\
\hline Mathematics & 54,228 & 60.520 & 24.771 & 613.578 & -0.862 & -0.193 \\
\hline
\end{tabular}

Especially in case of Mathematics, there is approximately 17 points difference in the mean value between all applicants and applicants accepted for studies. This means, that Mathematics is the biggest problem for applicants during examination process.

Table 4. Descriptive Statistics for the Whole Sample of Applicants Accepted for Studies

\begin{tabular}{|l|l|l|l|l|l|l|}
\hline & N & Mean & Std. Deviation & Variance & Kurtosis & Skewness \\
\hline English & 24,653 & 77.018 & 12.062 & 145.490 & 0.016 & -0.485 \\
\hline Mathematics & 24,653 & 77.883 & 16.011 & 256.353 & 0.016 & -0.369 \\
\hline
\end{tabular}

\section{RESULTS OF ENTRANCE EXAMS FOR STUDENTS FROM VIETNAM}

The number of applications from Vietnam (see Table 5) is decreasing for the last three years. But acceptance rate (AR) of students from Vietnam is continuing to increase. The decreasing number of applicants is caused by the fact that the newer generation of applicants does not have Vietnam citizenship but Czech one because they are already born in the Czech Republic as descendants of people with Vietnam citizenship living in Czech Republic.

Table 5. Number of Applicants from Vietnam based on the Years and Faculty

\begin{tabular}{|r|r|r|r|r|r|r|r|r|r|r|r|r|r|}
\hline & \multicolumn{2}{|c|}{ FFA } & \multicolumn{2}{|c|}{ FIS } & \multicolumn{2}{|c|}{ FMJH } & \multicolumn{2}{|c|}{ FIR } & \multicolumn{2}{|c|}{ FBA } & \multicolumn{2}{|c|}{ FE } & Total \\
\cline { 2 - 15 } & N & AR & N & AR & N & AR & N & AR & N & AR & N & AR & N \\
\hline 2009 & 54 & $44 \%$ & 33 & $76 \%$ & 13 & $38 \%$ & 28 & $57 \%$ & 49 & $33 \%$ & 15 & $7 \%$ & 192 \\
\hline 2010 & 64 & $50 \%$ & 23 & $61 \%$ & 6 & $33 \%$ & 29 & $34 \%$ & 61 & $43 \%$ & 15 & $13 \%$ & 198 \\
\hline 2011 & 86 & $40 \%$ & 40 & $43 \%$ & 8 & $50 \%$ & 44 & $57 \%$ & 84 & $42 \%$ & 19 & $5 \%$ & 281 \\
\hline 2012 & 68 & $54 \%$ & 56 & $55 \%$ & 10 & $70 \%$ & 63 & $41 \%$ & 100 & $37 \%$ & 21 & $24 \%$ & 318 \\
\hline 2013 & 79 & $35 \%$ & 62 & $44 \%$ & 7 & $57 \%$ & 60 & $50 \%$ & 107 & $28 \%$ & 16 & $19 \%$ & 331 \\
\hline 2014 & 57 & $40 \%$ & 45 & $29 \%$ & 5 & $60 \%$ & 38 & $45 \%$ & 91 & $54 \%$ & 15 & $7 \%$ & 251 \\
\hline 2015 & 13 & $38 \%$ & 25 & $60 \%$ & 3 & $0 \%$ & 13 & $46 \%$ & 15 & $33 \%$ & 1 & $0 \%$ & 70 \\
\hline 2016 & 10 & $60 \%$ & 14 & $57 \%$ & 1 & $100 \%$ & 8 & $50 \%$ & 8 & $63 \%$ & 4 & $50 \%$ & 45 \\
\hline Total & 431 & & 298 & & 53 & & 283 & & 515 & & 106 & & 1,686 \\
\hline
\end{tabular}

Note: $\mathrm{N}=$ number of applicants, $\mathrm{AR}=$ Acceptance Rate

Table 6 provides basic statistical characteristics about applicants with Vietnam citizenship. Based on number of records from entrance exams $(1,108$ - see Table 6$)$ and total number of applicants $(1,686)$ we calculated, that only $65.7 \%$ of applicants took the entrance exam. The mean value of the points from English is 72.857 and from Mathematics 67.367 with standard deviation 16.567 / 21.743. When we compare those numbers with number in Table 3 we see that applicants with Vietnam citizenship have better results in Mathematics and English than results analyzed for all applicants in whole sample. . 
Table 6. Descriptive Statistics for the whole sample of applicants with Vietnam Citizenship

\begin{tabular}{|l|l|l|l|l|l|l|}
\hline & $\mathbf{N}$ & Mean & Std. Deviation & Variance & Kurtosis & Skewness \\
\hline English & 1,108 & 72.857 & 16.567 & 274.455 & 1.918 & -1.090 \\
\hline Mathematics & 1,108 & 67.367 & 21.743 & 472.758 & -0.225 & -0.516 \\
\hline
\end{tabular}

Table 7 shows important information. The mean of points from mathematics is decreasing in time for FIS and FIR but for FFA is increasing and for FBA relatively stable in time. Skewness is in almost all cases with negative value which is between value $-0.08--0.8$. There is only one difference in case of FIS in year 2016 where Skewness has high positive value 0.8 .

Table 7. Detailed Descriptive Statistics for Mathematics for Applicants with Vietnam Citizenship in Detail of Year and Faculty

\begin{tabular}{|l|l|l|l|l|l|l|l|l|}
\hline Year & Faculty & $\mathbf{N}$ & Mean & Median & Std. Deviation & Variance & Kurtosis & Skewness \\
\hline 2009 & FFA & 49 & 62.041 & 70 & 33.290 & $1,108.248$ & -0.669 & -0.744 \\
\hline 2009 & FIS & 24 & 72.083 & 70 & 18.703 & 349.819 & -1.176 & -0.129 \\
\hline 2009 & FIR & 26 & 71.923 & 77.5 & 24.003 & 576.154 & -0.258 & -0.816 \\
\hline 2009 & FBA & 29 & 76.552 & 80 & 17.632 & 310.899 & 0.298 & -0.869 \\
\hline 2011 & FFA & 77 & 67.662 & 70 & 19.032 & 362.227 & -0.943 & -0.171 \\
\hline 2011 & FIS & 13 & 71.923 & 65 & 20.569 & 423.077 & -0.180 & -0.283 \\
\hline 2011 & FIR & 36 & 71.250 & 77.5 & 20.646 & 426.250 & -0.825 & -0.601 \\
\hline 2011 & FBA & 66 & 64.242 & 67.5 & 22.001 & 484.033 & -0.609 & -0.204 \\
\hline 2013 & FFA & 71 & 63.732 & 60 & 21.107 & 445.513 & -1.153 & 0.101 \\
\hline 2013 & FIS & 38 & 60.263 & 62.5 & 20.728 & 429.659 & -0.627 & -0.080 \\
\hline 2013 & FIR & 43 & 64.698 & 68 & 22.559 & 508.930 & -0.679 & -0.168 \\
\hline 2013 & FBA & 77 & 62.273 & 65 & 19.391 & 376.017 & -0.527 & -0.368 \\
\hline 2016 & FFA & 8 & 70.625 & 77.5 & 18.408 & 338.839 & -0.995 & -0.750 \\
\hline 2016 & FIS & 12 & 56.667 & 55 & 16.967 & 287.879 & 1.019 & 0.812 \\
\hline 2016 & FIR & 6 & 54.833 & 55.5 & 36.471 & $1,330.167$ & -0.476 & -0.328 \\
\hline 2016 & FBA & 6 & 70.833 & 67.5 & 13.934 & 194.167 & -1.552 & 0.493 \\
\hline
\end{tabular}

Table 8 shows similar information but for English language. Mean of points from English has cyclical character for all faculties. Values are decreasing and increasing in time. In case of FFA the lowest mean is 55 point and the highest mean is 82 . In case of FIS is it between 56 and 73, FIR 68 and 75 and FBA between 73 and 78 points. We see that better results are at the FBA in comparison with other faculties. The second one is FIR and the last one is FIS. 
Applicant's Results for Studies from Russia and Vietnam at the University of Economics, Prague

Table 8. Detailed Descriptive Statistics for English Applicants with Vietnam Citizenship in Detail of Year and Faculty

\begin{tabular}{|l|l|l|l|l|l|l|l|l|}
\hline Year & Faculty & $\mathbf{N}$ & Mean & Median & Std. Deviation & Variance & Kurtosis & Skewness \\
\hline 2009 & FFA & 49 & 55.837 & 62 & 30.124 & 907.473 & -0.640 & -0.622 \\
\hline 2009 & FIS & 24 & 65.417 & 65 & 15.598 & 243.297 & -0.105 & -0.309 \\
\hline 2009 & FIR & 26 & 71.962 & 76 & 16.513 & 272.678 & -0.003 & -0.745 \\
\hline 2009 & FBA & 29 & 78.483 & 78 & 13.945 & 194.473 & -0.392 & -0.519 \\
\hline 2011 & FFA & 77 & 72.987 & 74 & 14.642 & 214.381 & -0.194 & -0.581 \\
\hline 2011 & FIS & 13 & 56.769 & 58 & 17.730 & 314.359 & -0.125 & -0.403 \\
\hline 2011 & FIR & 36 & 73.778 & 76.5 & 13.269 & 176.063 & 0.534 & -1.057 \\
\hline 2011 & FBA & 66 & 73.970 & 77 & 15.549 & 241.784 & -0.242 & -0.738 \\
\hline 2013 & FFA & 71 & 77.606 & 82 & 13.655 & 186.471 & 0.688 & -0.962 \\
\hline 2013 & FIS & 38 & 73.842 & 78 & 16.264 & 264.515 & -0.276 & -0.601 \\
\hline 2013 & FIR & 43 & 75.791 & 77.5 & 12.842 & 164.919 & -0.826 & -0.226 \\
\hline 2013 & FBA & 77 & 76.026 & 80 & 16.005 & 256.157 & 1.963 & -1.290 \\
\hline 2016 & FFA & 8 & 67.750 & 69 & 15.872 & 251.929 & -0.753 & 0.257 \\
\hline 2016 & FIS & 12 & 71.833 & 71 & 16.959 & 287.606 & -1.073 & -0.221 \\
\hline 2016 & FIR & 6 & 68.667 & 65.75 & 17.218 & 296.467 & -2.429 & 0.285 \\
\hline 2016 & FBA & 6 & 75.333 & 78 & 12.437 & 154.667 & -0.407 & -0.644 \\
\hline
\end{tabular}

Estimated regression model coefficients for the entire time period is shown in Table 9. This function compares results from entrance exams and information if the student finished his studies successfully or not. Students that are still studying are excluded. This function provides information about dependency between the amount of points received during entrance exam and its influence into probability of finishing studies.

Table 9. Logit function

\begin{tabular}{|l|l|l|l|l|}
\hline & \multicolumn{1}{|c|}{$\boldsymbol{\beta}$} & Std. Error & Wald Test & $\operatorname{Exp}(\beta)$ \\
\hline Increment - Points from Entrance Exam $\left(\beta_{1}\right)$ & .042 & .007 & 40.167 & 1.043 \\
\hline Constant $\left(\beta_{0}\right)$ & -7.244 & 1.067 & 46.065 & .001 \\
\hline
\end{tabular}

Correlation between analyzed variables is weak and is 1:0.042 on average. 


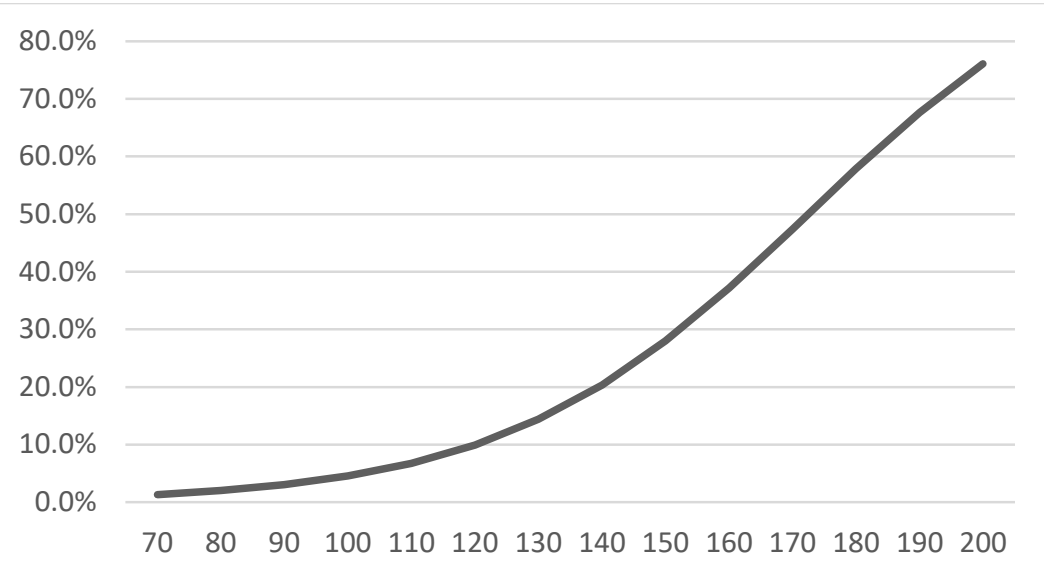

Figure 1. Correlation Obtained Points and Completion of Studies - Vietnamese Students

Figure 1 shows that for $50 \%$ probability to complete successfully studies it is necessary to obtain more than 170 points in entrance exams. In the case that student gets maximum 200 points, the probability of successfully completing study is a little higher than $75 \%$. $(76.1 \%)$

\section{RESULTS OF ENTRANCE EXAMS FOR STUDENTS FROM RUSSIA}

Similar analysis as for Vietnam student was processed for applicants with Russian citizenship.

The biggest difference shown in Table 10 is number of applicants from Russia in comparison with applicants from Vietnam. The number of applicants with Russian citizenship is higher than applicants with Vietnam citizenship. The second difference is in acceptation rate, which is smaller in case of Russian students as is show in Table 10.

Table 10. Number of Applicants from Russia Based on the Years and Faculty

\begin{tabular}{|c|c|c|c|c|c|c|c|c|c|c|c|c|c|}
\hline \multirow[b]{2}{*}{ Year } & \multicolumn{2}{|c|}{ FFA } & \multicolumn{2}{|c|}{ FIS } & \multicolumn{2}{|c|}{ FMJH } & \multicolumn{2}{|c|}{ FIR } & \multicolumn{2}{|c|}{ FBA } & \multicolumn{2}{|c|}{ FE } & \multirow[t]{2}{*}{ Total } \\
\hline & $\mathbf{N}$ & AR & $\mathbf{N}$ & AR & $\mathbf{N}$ & AR & $\mathbf{N}$ & AR & $\mathbf{N}$ & AR & $\mathbf{N}$ & AR & \\
\hline 2009 & 227 & $37 \%$ & 160 & $49 \%$ & 26 & $15 \%$ & 102 & $32 \%$ & 294 & $24 \%$ & 44 & $0 \%$ & 853 \\
\hline 2010 & 173 & $36 \%$ & 151 & $32 \%$ & 24 & $25 \%$ & 80 & $35 \%$ & 276 & $21 \%$ & 27 & $11 \%$ & 731 \\
\hline 2011 & 190 & $24 \%$ & 139 & $37 \%$ & 35 & $14 \%$ & 92 & $30 \%$ & 285 & $21 \%$ & 44 & $0 \%$ & 785 \\
\hline 2012 & 196 & $43 \%$ & 137 & $28 \%$ & 19 & $21 \%$ & 114 & $28 \%$ & 335 & $25 \%$ & 27 & $7 \%$ & 828 \\
\hline 2013 & 267 & $21 \%$ & 181 & $35 \%$ & 23 & $13 \%$ & 144 & $38 \%$ & 350 & $8 \%$ & 40 & $25 \%$ & 1,005 \\
\hline 2014 & 319 & $28 \%$ & 227 & $26 \%$ & 41 & $37 \%$ & 170 & $36 \%$ & 335 & $12 \%$ & 44 & $25 \%$ & 1,136 \\
\hline 2015 & 263 & $21 \%$ & 222 & $38 \%$ & 26 & $35 \%$ & 148 & $43 \%$ & 383 & $31 \%$ & 35 & $29 \%$ & 1,077 \\
\hline 2016 & 157 & $19 \%$ & 197 & $27 \%$ & 15 & $13 \%$ & 119 & $50 \%$ & 289 & $29 \%$ & 35 & $26 \%$ & 812 \\
\hline Total & 1,792 & & 1,414 & & 209 & & 969 & & 2,547 & & 296 & & 7,227 \\
\hline
\end{tabular}

Note: $\mathrm{N}=$ number of applicants, $\mathrm{AR}=$ Acceptance Rate

Table 11 provides basic statistical characteristics about applicants with Russian citizenship. Based on number of records from entrance exams (3,044 - see Table 11) and total number of Russian applicants $(7,277)$ we calculated, that only $42.1 \%$ of applicants took the entrance exam. Mean value of the points from English is 69.132 (applicants with Russian citizenship have worse results in comparison with applicants with Vietnam citizenship) and from Mathematics 71.610 (better results in comparison 
Applicant's Results for Studies from Russia and Vietnam at the University of Economics, Prague

with applicants with Vietnam citizenship nationality) with standard deviation 19.863/24.436. When we compare those numbers with number in Table 3 we see that applicants with Russian citizenship have better result in Mathematics and English than results analyzed for all applicants from the whole sample.

Table 11. Number of Applicants from Russia Based on the Years and Faculty

\begin{tabular}{|l|l|l|l|l|l|l|}
\hline & $\mathbf{N}$ & Mean & Std. Deviation & Variance & Kurtosis & Skewness \\
\hline English & 3,044 & 69.132 & 19.863 & 274.455 & 2.869 & -1.454 \\
\hline Mathematics & 3,044 & 71.610 & 24.436 & 472.758 & 0.734 & -1.033 \\
\hline
\end{tabular}

Table 12 shows information about the mean of points from mathematics. This number is decreasing in time for FIS, FBA and FIR but increasing for FFA. The highest mean has been identified for applicants for FFA and lowest for applicants at the FBA.

Table 12. Detailed Descriptive Statistics for Mathematics for Applicants with Russian Citizenship in Detail of Year and Faculty

\begin{tabular}{|l|l|l|l|l|l|l|l|l|}
\hline Year & Faculty & N & Mean & Median & Std. Deviation & Variance & Kurtosis & Skewness \\
\hline 2009 & FFA & 212 & 44.741 & 45 & 43.317 & $1,876.354$ & -1.802 & 0.093 \\
\hline 2009 & FIS & 82 & 77.988 & 80 & 19.227 & 369.667 & 0.131 & -0.847 \\
\hline 2009 & FIR & 58 & 75.862 & 80 & 20.798 & 432.577 & 0.435 & -0.887 \\
\hline 2009 & FBA & 119 & 78.445 & 85 & 22.631 & 512.181 & 1.446 & -1.416 \\
\hline 2011 & FFA & 97 & 74.588 & 80 & 18.124 & 328.474 & 0.037 & -0.775 \\
\hline 2011 & FIS & 64 & 72.813 & 75 & 19.556 & 382.440 & -1.158 & -0.232 \\
\hline 2011 & FIR & 51 & 77.353 & 80 & 18.449 & 340.353 & -0.283 & -0.629 \\
\hline 2011 & FBA & 102 & 68.971 & 70 & 21.861 & 477.890 & -0.452 & -0.409 \\
\hline 2013 & FFA & 135 & 72.259 & 80 & 21.732 & 472.283 & -0.304 & -0.749 \\
\hline 2013 & FIS & 86 & 66.977 & 70 & 21.778 & 474.282 & -0.090 & -0.403 \\
\hline 2013 & FIR & 69 & 74.623 & 81 & 22.385 & 501.091 & -0.896 & -0.509 \\
\hline 2013 & FBA & 56 & 64.482 & 65 & 19.876 & 395.054 & -0.721 & -0.182 \\
\hline 2016 & FFA & 83 & 76.506 & 80 & 18.158 & 329.716 & -0.173 & -0.603 \\
\hline 2016 & FIS & 98 & 70.510 & 75 & 23.698 & 561.593 & -0.593 & -0.600 \\
\hline 2016 & FIR & 62 & 70.581 & 81 & 25.143 & 632.149 & -0.631 & -0.715 \\
\hline 2016 & FBA & 144 & 69.271 & 70 & 20.509 & 420.618 & 0.341 & -0.722 \\
\hline
\end{tabular}

Table 13 shows similar information but for Mathematics. Mean of points from mathematics has increasing tendency in case of FFA and FIS but is decreasing in case of FIR. This is absolutely different tendency in comparison with results from whole sample of all applicants which knowledge are lower than knowledge or applicants from Russia and Vietnam. 
Table 13. Detailed Descriptive Statistics for English for Applicants with Russian Citizenship in Detail of Year and Faculty

\begin{tabular}{|l|l|l|l|l|l|l|l|l|}
\hline Year & Faculty & N & Mean & Median & Std. Deviation & Variance & Kurtosis & Skewness \\
\hline 2009 & FFA & 212 & 40.472 & 50 & 38.427 & $1,476.630$ & -1.795 & 0.036 \\
\hline 2009 & FIS & 82 & 70.878 & 72 & 13.885 & 192.800 & 1.075 & -0.722 \\
\hline 2009 & FIR & 58 & 71.690 & 74 & 17.407 & 302.990 & -0.945 & -0.233 \\
\hline 2009 & FBA & 119 & 73,076 & 78 & 17,766 & 315,647 & $-0,016$ & $-0,819$ \\
\hline 2011 & FFA & 97 & 73.691 & 76 & 15.688 & 246.112 & 0.738 & -0.923 \\
\hline 2011 & FIS & 64 & 66.313 & 66 & 17.689 & 312.917 & -0.515 & -0.013 \\
\hline 2011 & FIR & 51 & 67.588 & 67 & 18.743 & 351.287 & 1.933 & -0.865 \\
\hline 2011 & FBA & 102 & 72,706 & 74 & 14,155 & 200,368 & 0,558 & $-0,660$ \\
\hline 2013 & FFA & 135 & 72.459 & 76 & 15.546 & 241.668 & 0.002 & -0.672 \\
\hline 2013 & FIS & 86 & 69.047 & 70 & 16.839 & 283.551 & 2.065 & -0.828 \\
\hline 2013 & FIR & 69 & 68.094 & 67.5 & 15.762 & 248.451 & 3.837 & -0.973 \\
\hline 2013 & FBA & 56 & 67,911 & 70 & 17,050 & 290.701 & $-0,176$ & $-0,476$ \\
\hline 2016 & FFA & 83 & 75.494 & 78 & 13.789 & 190.131 & 0.070 & -0.665 \\
\hline 2016 & FIS & 98 & 73.653 & 76 & 16.482 & 271.672 & -0.126 & -0.627 \\
\hline 2016 & FIR & 62 & 65.315 & 67.5 & 17.260 & 297.920 & 2.218 & -1.220 \\
\hline 2016 & FBA & 144 & 71,826 & 74 & 14,847 & 220,424 & $-0,425$ & $-0,451$ \\
\hline
\end{tabular}

Estimated regression model coefficients for the entire time period is show in Table 14. Correlation between two analyzed variables is weak and is 1:0.037 on average.

Table 14. Logit Function

\begin{tabular}{|l|l|l|l|l|}
\hline & $\beta$ & Std. Error & Wald Test & $\operatorname{Exp}(\beta)$ \\
\hline Increment - Points from Entrance Exam $\left(\beta_{1}\right)$ & .037 & .004 & 81.845 & 1.038 \\
\hline Constant $\left(\beta_{\circ}\right)$ & -6.614 & .677 & 95.535 & .001 \\
\hline
\end{tabular}

Figure 2 shows that for $50 \%$ probability to complete successfully studies is necessary to obtain a little less than 170 points in entrance exams. In the case that student gets maximum 200 points, the probability of successfully completing study is approximately $70 \%$. 
Applicant's Results for Studies from Russia and Vietnam at the University of Economics, Prague

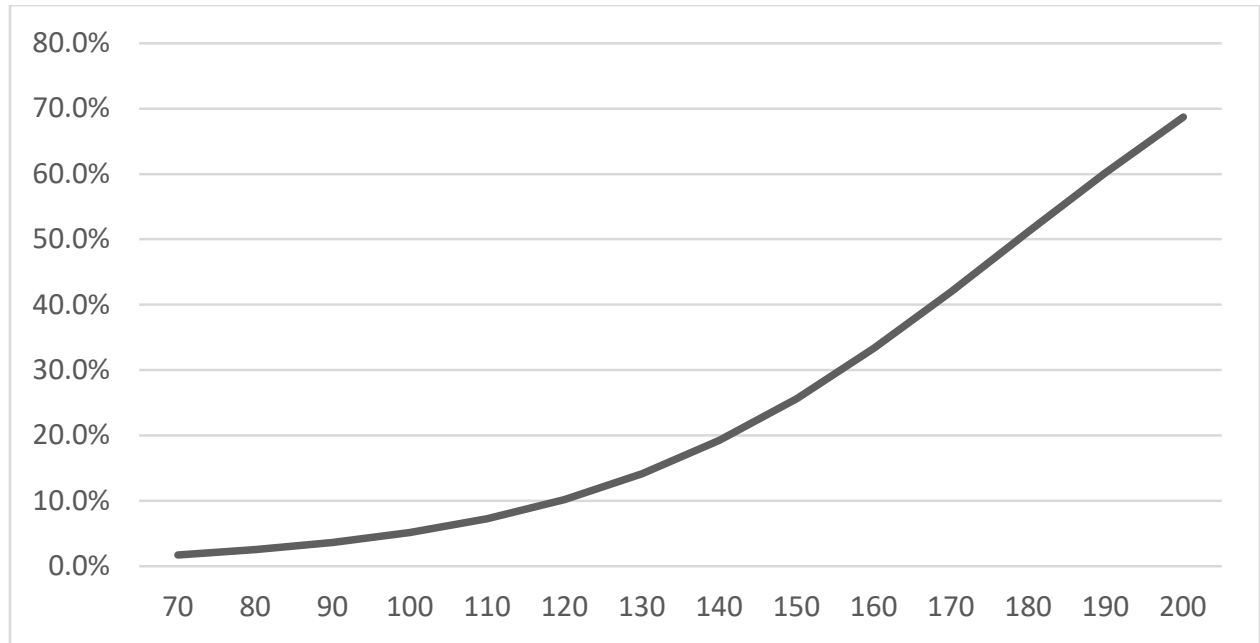

Figure 2. Correlation Obtained Points and Completion of Studies - Russian Students

\section{RESEARCH Questions AsSESSMENT}

Based on presented data we are able to make assessment to prior formulated research questions.

The RQ 1: "Russian applicants have higher score from Mathematics than Vietnamese ones" is accepted, because the average obtained points of Vietnamese applicants is 67.367 and for Russian students is the average 71.610. (Table 6 and Table 11)

The RQ 2: "Russian applicant have higher score from English than Vietnamese ones" is rejected, because the Vietnamese applicant's average is 72.857 obtained points and for Russian applicants is the average value 69.132 points. (Table 6 and Table 11)

The RQ 3: "Average score from English is increasing on undergraduate level by both nationalities" is rejected, because results for majority of faculties oscillate and do not follow clear trend in investigated period. (Tables 7-8)

The RQ 4: "Average score from Mathematics is increasing on undergraduate level by both nationalities" is rejected, because results for majority of faculties oscillate and do not follow clear trend in investigated period. There are only two identified exceptions - FIS for Vietnamese applicants in mathematics - but the trend is continuing to decrease from 72.083 points in 2009 to 56.667 in 2016 and the same entity for FIR from 71.923 points in 2009 to 54.833 points in 2016 (Tables 1213).

Conclusions from our research questions are not very surprising, because the education system of former Soviet Union was mainly focused, especially on high schools, on mathematic education. In comparison to Vietnamese education system is appearing, that Vietnamese applicants obtain by entrance exams in average worse assessment than Russian ones.

Open issues are in further research of social aspects of entrance exams by citizenship. The first very often discussed factor is motivation related with geopolitical situation. The trend in number of Russian applicants for Czech study programs is decreasing in last two years (Table 10). On the other hand the number of Russian applicants and students in increasing in paid English study programs at the same university. 
Maryska, Doucek, \& Nedomova

\section{CONCLUSION}

This paper is a result of a long-term project realized at the University of Economics, Prague that helps management of UEP and faculties to answer essential questions concerning entrance examinations, relation between entrance examinations results and results of regularly examinations, rate of graduate students etc.

By analyzing the eight-year time series, we discovered that 8,913 foreign students (from Vietnam and Russia) are admitted to the UEP and that this is decreasing during the past three years. Foreign students mostly apply to the FIR and the FBA.

The analysis of mathematics entrance test results identified a slightly negatively skewed normal distribution and a practically zero average value. The quantile analysis proved higher data consistency with respect to English entrance exam results and lower data consistency with respect to mathematics entrance exam results. The mean of the points obtained for English entrance exams is 72 and the mean of the points obtained for mathematics entrance exams is 67 in case of applicants with Vietnam citizenship and 69 (English) resp. 71 (mathematics) in case of applicants with Russian citizenship - RQ 1 and RQ 2 assessment.

RQ 3 and RQ 4 did not identify any clear trends in progress of obtained points by assessment of entrance examinations. Both were rejected.

Thanks to this research and this paper, we find out plenty of new knowledge about structure of applicants for study, their knowledge and differences based on the citizenship, type of high school, etc. Very important information is success rate based on the study subjects, years of study, etc. Further important information for deans of faculties and also for the management of the UEP is modeling the graduation probability using logit model. This model presents to stakeholders correlation between number of obtained points in entrance exams and the probability of successfully completion of studies. For this data set (Vietnamese and Russian students) it seems to be relevant to accept for study in economics student that obtain more than 180 points in entrance exams. The logit model analysis results more positive for Vietnamese students.

Next step planned for this is year is analysis of relation among results of Mock Entrance Exams Entrance Exams - Study Results. This is long-term plan. In next 5 years, we should be able to answer question if there is some probability, that students failed during standard entrance exams when these students pass mock exams for example because they were in stress?

\section{ACKNOWLEDGEMENTS}

Paper was processed with contribution of long term institutional support of research activities by Faculty of Informatics and Statistics, University of Economics, Prague (IP 400040).

\section{REFERENCES}

Azar, A. (2005). Analysis of Turkish high-school physics-examination questions and university entrance exams questions according To Blooms' Taxonomy. Journal of Turkish Science Education (TUSED), 2(2), 144-150.

Flegl, M., \& Vltavska, K. (2013). Efficiency at Faculties of Economics in the Czech public higher education institutions: Two different approaches. International Education Studies, 6(10), 1-12.

Hanclova, J. (2015). Comparison of production performance in information and communication sectors in the EU selected countries. Proceedings of the IDIMT 2015 - Information Technology and Society - Interaction and Interdependence - 23rd Interdisciplinary Information Management Talks, 111-118.

Hanclova, J., Rozehnal, P., Ministr, J., \& Tvrdikova, M. (2015). The determinants of IT adoption in SMEs in the Czech-Polish border areas. Information Technology for Development, 21(3), 426-444.

Kitao, S. K., \& Kitao, K. (2009). An analysis of Japanese university entrance exams using corpus-based tools. Retrieved January 5, 2017, from http://www.j-let.org/ wcf/proceedings/d-053.pdf 
Applicant's Results for Studies from Russia and Vietnam at the University of Economics, Prague

Klasik, D. (2012). The act of enrollment: The college enrollment effects of state-required college entrance exam testing. Stanford University. Retrieved January 5, 2017, from http://cepa.stanford.edu/sites/default/files/klasik writingsample satact.pdf

Kohanova, I. (2012). Analysis of university entrance test from mathematics. Acta Didactica Universitatis Comenianae Mathematics, 12, 31-46.

Kuncova, M., \& Mulac, P. (2015). Higher professional education funding systems in selected European countries and in the Czech Republic. Turkish Online Journal of Educational Technology, Special Issue for INTE 2015, 293-300.

Kuncova, M., \& Wasserbauer, P. (2007). Discrete event simulation - Helpdesk model in SIMPROCESS. Proceedings of the ECMS 2007 [CD-ROM], 105-109.

Musil, P., \& Fischer, J. (2015). Měření výstupu vzdělávacích služeb. Politická ekonomie, 63(2), 167-184.

Nedomova, L., Doucek, P., \& Maryška, M. (2015). ICT professionals in the Czech Economy, structural changes in human resources. Proceedings of the 11th International Conference on Strategic Management and Its Support by Information Systems 2015, 419-430.

Nedomova, L., Maryska, M., \& Doucek, P. (2014). The enterprise architect role - And its mission in corporate information and communication technology - A Czech study. Journal of Applied Economic Sciences, 9(1), 88100.

OECD (2009). OECD reviews of tertiary education: Czech Republic. Retrieved January 3, 2017, from http://www.oecd-ilibrary.org/education/oecd-reviews-of-tertiary-education-czech-republic2009 9789264049079-en

Pavlicek, A. (2013). Possibilities of social networks in education. Proceedings of the 10th International Conference on Strategic Management and Its Support by Information Systems 2013, 147-154.

Razmjoo, A. S., \& Tabrizi, H. (2010). A content analysis of the TEFL M.A. entrance examinations (Case study: Majors courses). Pan-Pacific Association of Applied Linguistics, 14(1), 159-170.

Rezankova, H. (2010). Analyza dat z dotazníkových šetréní Praha: Professional Publishing.

Reznicek, V., Smutny, Z., Kalina, J., \& Galba, A. (2013). Knowledge sharing as a problem of the individual nature of knowledge. Proceedings of the European Conference on Knowledge Management, 920-925.

Sigmund, T. (2015). Vztah etického a ekonomického chování. Politická ekonomie, 63(2), 223-243.

Sperkova, L., \& Nedomova, L. (2015). Are the entrance exams results of applicants to university in English and German languages equally good? Turkish Online Journal of Educational Technology, Special Issue for INTE 2015, 44-50.

Stastna, V., \& Walterova, E. (2014). The Bologna Process in the Czech Republic. The Bologna Process in Central and Eastern Europe, pp 83-114.

Vysokeskoly. (2010). Podminky studia na vysokych skolach v Ceske republice. Retrieved January 5, 2017, from. http://www.vysokeskoly.cz/clanek/podminky-studia-na-vysokych-skolach-v-ceske-republice 


\section{BIOGRAPHIES}

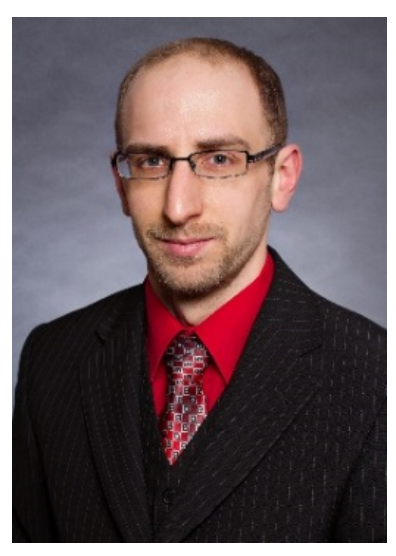

Milos Maryska graduated from the Faculty of Informatics and Statistics at the University of Economic, Prague, in Information Technologies in 2006. In year 2010 he graduated in Applied Information Technologies and gained degree Ph.D. and since year 2015 is working as an associate professor at the University of Economics, Prague. Within his pedagogic and research work he focuses on IT financial management, project management, management of economics of business informatics, Business Intelligence, Industry 4.0 and ERP systems. He is co-author of 5 books, and author and co-author of several conference papers and in journal articles in journal with Impact factor. He works as a manager in the company Deloitte Advisory and is responsible for topics in are of Industry 4.0.

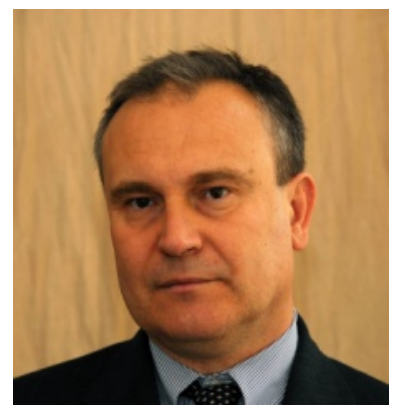

Petr Doucek - Head of the Department of System Analysis, University of Economics, Prague, full professor since 2007 in Informatics. His research and education activities are focused on information security, project management and managerial science. He has been and is the principal investigator of two projects funded by Czech Science Foundation or The Ministry of Education, Youth and Sports of the Czech Republic and investigator on further six projects as team member. He is actual a member of several program committees of conferences in Europe, America and Asia. He participated on approximately 30 projects for Czech and international companies. Member of Czech Society for System Integration, International Organization for Standardization (SC27 ISO Information technology security).

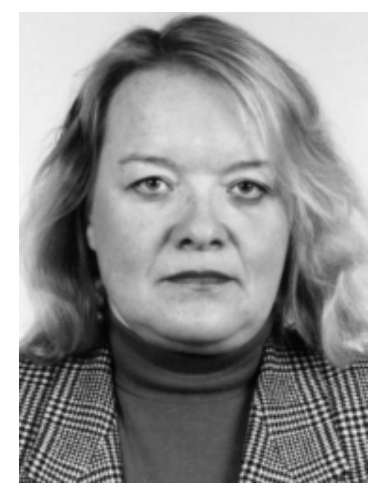

Lea Nedomova has been working as assistant professor of the Department of System Analysis at the Faculty of Informatics and Statistics at the University of Economics, Prague since 1996. Her main research and development topics include system approach to global society, sustainable development and its relation to integrated management system and its components. Further area of her interest is gender aspects of Information technology implementation and operation. 